\title{
A hidrogén lehetséges honvédelmi (katonai) alkalmazása
}

A hadviselés a történelem hajnala óta a társadalom egyik leginkább erőforrásigényes tevékenysége. A katonai célra felhasznát erőforrások közül az energiaigény egészen a múlt század elejéig elsősorban a hadiiparban jelentkezett. A belső égésű motorok, valamint a villamosság megjelenését követően azonban, már a harctéren is mérhető és logisztikailag biztosítandó a nem emberi vagy állati eredetű energia. Mivel a katonai és civil technológiák az esetek többségében azonosak - vagy legalábbis közös tudományos kutatási eredményeken alapulnak -, nem meglepő, hogy amilyen mértékben napjainkban nő a civilizáció energiaigénye, legalább ugyanolyan ütemben nő a katonai műveletek energiaigénye is. A második világháború végére egy amerikai katona tevékenysége napi 4 liter olaj-ekvivalens energiát ${ }^{2}$ igényelt. Ez a szám a vietnámi háború alatt 33 liter, az első öböl-háború idején pedig már 81 liter volt [1]. A Magyar Honvédséggel szemben természetesen mások az elvárások, de ebben az esetben is nyilvánvaló a növekvő energiaigény. Csupán ez elmúlt években, évente mintegy félmillió literrel nőtt a Magyar Honvédség által felhasznált fosszilis üzemanyagok mennyisége [2].

A Magyar Honvédség elkötelezett abban, hogy a Nemzeti Energia és Klímatervvel összhangban csökkentse a müködéséhez szükséges fosszilis üzemanyag-mennyiséget, de ez nyilvánvalóan nem történhet a meglévő képességek rovására, sőt az elkövetkezendő időszakban a Zrínyi 2026 Honvédelmi és Haderőfejlesztési Program részeként a Magyar Honvédség számos új képességre tesz majd szert. A két egymásnak némileg ellentmondó cél csak úgy valósítható meg, ha a Magyar Honvédség adaptálja a legkorszerűbb energetikai eljárásokat és technológiákat, ideértve a hidrogénen alapuló megoldásokat is.

$\mathrm{Az}$ a fosszilis energiahordozó-mennyiség, amelyet összhangban a nemzeti célkitűzésekkel - a hidrogén-alapú technikákkal meg tudunk takarítani a Magyar Honvédség működése során, igen fontos, hiszen ennek révén csökken az ország energiafüggősége és előnyös a környezet védelme szempontjából is. Ebben a tekintetben a Magyar Honvédség nem különbözik az állami szféra más szervezeteitől, de van néhány olyan részterület, ahol a speciális kato-

ÖSSZEFOGLALÁS: 2020. április 27-én az Innovációs és Technológiai Minisztérium védnökségével megalakult a Nemzeti Hidrogéntechnológiai Platform (NHTP). Az alapító tagok egyike a Magyar Honvédség Modernizációs Intézete. A szervezethez csatlakozó tagok mindegyike elkészítette a saját hidrogénnel kapcsolatos céljait, elképzeléseit. A tanulmány a Modernizációs Intézet által

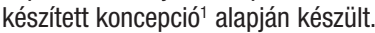

KULCSSZAVAK: Hidrogén, energia, energiatárolás, MH Modernizációs Intézet nai elvárások a legtöbb „civil” felhasználási módtól eltérő igényeket támasztanak a hidrogénre épülő energetikai technológiák terén. A továbbiakban ezeket az alkalmazási sajátosságokat kívánom bemutatni.

\section{E-MOBILTÁS - KÖZÚTI JÁRMÜVEK}

Bár a hadseregek sokszor hagyományosan úttörők egy technológia fejlesztése és felhasználása terén, sokszor mégis határozottan konzervatív módon választanak ki egyegy haditechnikai eszközt. Ennek oka a „civil” területét meghaladó megbízhatósági-biztonsági szempont prioritása. A legtöbb haderő a nagyobb, komplex haditechnikai eszközök beszerzése terén - elsősorban a költséghatékonyság miatt - legalább 10-20 éves életciklussal számol. A tervezett felújítások, korszerűsítések révén ez az időtartam akár a 30 évet is meghaladhatja. Ez azt jelenti, hogy a hadsereg nem engedheti meg magának egy technológiai zsákutca kockázatát, ezért sokszor a jól bevált, hagyományos eszközöket részesíti előnyben.

1. ábra. A hidrogénhajtású SURUS-platform összkerékmeghajtású és -kormányzású. Terepen is képes autonóm módon közlekedni (Forrás: General Motors)

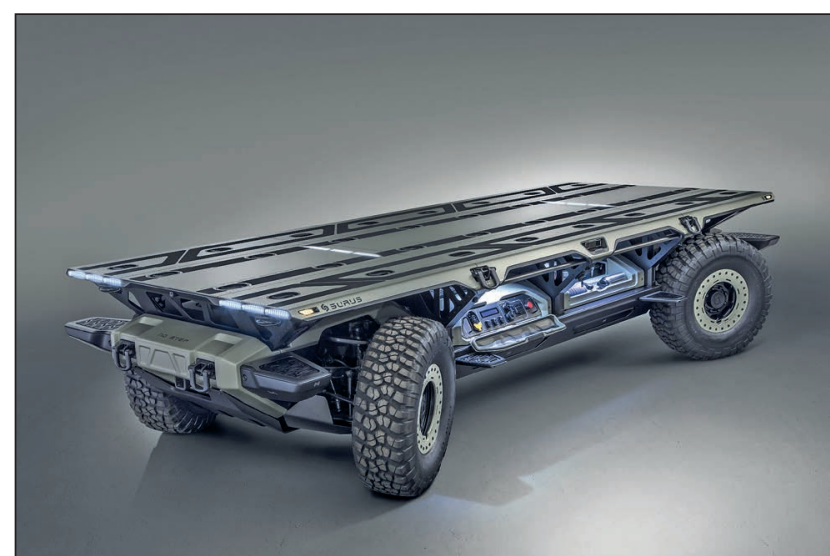

ABSTRACT: On 27th April 2020 the National Platform of Hydrogen Technology has been founded by the patronage of Ministry for Innovation and Technology. One of the founder members is the Hungarian Defence Forces Modernisation Institute. It was expected to all joining organisation to present a short study to write about its goals and ideas about Hydrogen. This paper is based on the study of Modernisation Institute. Further information: https:// www.hfc-hungary.org/platform/.

KEY WORDS: Hydrogen, energy, energy-storage, Modernisation Institute

\footnotetext{
Mk. alezredes, MH Modernizációs Intézet, NKE Hadtudományi és Honvédtisztképző Kar, Katonai Műszaki Doktori Iskola. ORCID: 0000-0003-2543-6049
} 


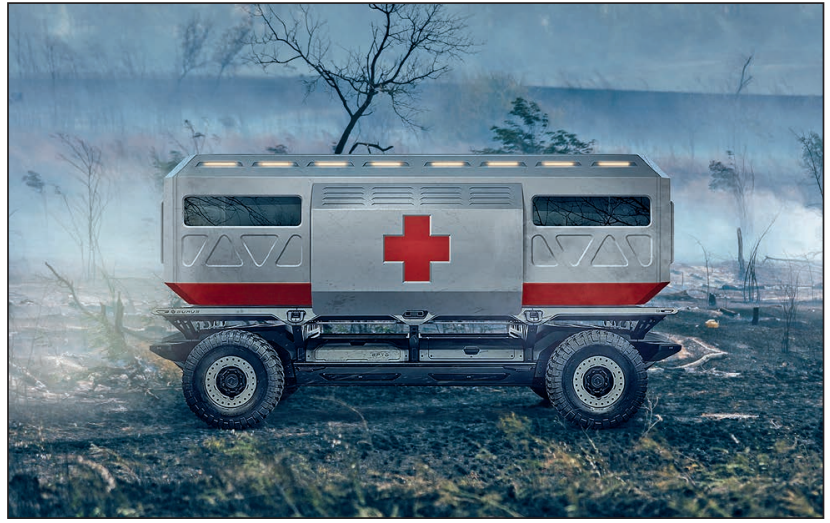

2. ábra. A SURUS-platform egyik lehetséges alkalmazása önjáró sebesültszállító (Forrás: General Motors)

Valószínűleg az említett okok magyarázzák, hogy a hadseregek általános felhasználású közúti jármúvei között még elhanyagolható a részben vagy egészben villamos hajtásláncú (ideértve a hidrogént tankoló elektromos motorral szerelt eszközöket is) gépjárművek aránya. Ugyanakkor nyilvánvaló, hogy a következő években egyre több és többféle villamos jármű megjelenésére számíthatunk a közutakon. Ez egy olyan globális trend, amely hatással van a védelmi szférára is, így már a közeljövőben várható, hogy zöldre festett, elektromos meghajtású katonai jármúvek jelenjenek meg az utakon. A távolabbi jövőben a speciális szárazföldi járművek, a harcjárművek is áttérnek az elektromos meghajtásra, napjainkban már ezen a területen is folynak kutatások.

Létezik azonban a katonai járműveknek egy olyan szegmense is, ahol az esetleges hidrogénüzemeltetésnek már most is komoly előnyei látszanak, amelyek képesek ellensúlyozni a technológia újszerűségéből eredő hátrányokat. Minden katonai jármű esetében követelmény, hogy lehetőség szerint minél nehezebben lehessen azt detektálni, míg a kimondottan felderítő célú járművek esetén ez az igény hatványozottan jelentkezik. Ezek azok az eszközök, amelyek egy katonai művelet során elsőként kerülhetnek szembe az ellenséggel, így a felderítő járművekkel szemben fokozott elvárás, hogy az információs fölény ${ }^{3}$ biztosítása érdekében rejtve tudjanak ténykedni. A jármű méretéből adódó optikai, szeizmikus stb. észlelhetőég nehezen csökkenthető, de a hagyományos dugattyús motoros járművek infravörös és akusztikus észlelhetősége radikálisan csökkenthető a villamos meghajtásra történő váltással [3].

A villamos járművek döntő többsége jelenleg akkumulátoros üzemü, amely technológia azonban egy katonai felderítő jármű esetében határozottan hátrányos. Itt is jelentkezik a jelenlegi közúti villamos járművek gyenge pontja, a korlátozott hatótávolság, de ennél is nagyobb probléma, hogy katonai műveleti területen még a legkorszerübb gyorstöltő eszközzel elérhető 8-10 perces feltöltési idő is megengedhetetlenül sok, arról nem is beszélve, hogy még a feltöltéshez szükséges villamos energiát is biztosítani kell valahonnan. Mivel nem életszerű, hogy a felderítő járművet diszkrét távolságban egy, a platóján aggregátort vagy többtonnányi akkumulátort szállító terepjáró tehergépkocsi kövessen, ezért ha egy ilyen nehezen észlelhető, ún. „low signature" felderítő jármú létrehozása a cél, jelenleg a hidrogén - PEM-cella ${ }^{4}$ - villanymotor összeállítás tűnik a legelőnyösebbnek.

Ezen a területen az amerikai General Motors kutatásai jutottak talán a legmesszebb. Egy éve még csak hidrogénes üzeművé alakított Chevrolet Coloradoval folytatott kí- sérletekről jelentek meg tudósítások, de 2020-ra jelentős innovációt mutattak be. A koncepció a SURUS ${ }^{5}$ nevet kapta [4]. A jármű legszembetűnőbb tulajdonsága a teljesen lapos kialakítás, amely egyrészt nyilvánvalóan egyszerűvé teszi többféle felépítmény alkalmazását, másrészt mivel a vezetőfülke is hiányzik - önvezető funkciót feltételez. Ez még közúton sem egyszerű, nemhogy terepen, de a GM mindenesetre bizakodó, 2023-ra mintegy 20 elektromos, illetve hidrogénüzemű járművet szándékozik piacra dobni. Magát a SURUS-t a mintegy 400 mérföldes ${ }^{6}$ hatótávolságával konvojkíséretre szánják.

\section{E-MOBILITÁS - LÉGI JÁRMÜVEK}

A drónok megjelenésével új lendületet kapott a villamos hajtású légi járművek fejlesztése, azonban az akkumulátoros közúti járműveknél jelentkező korlátozott hatótávolság ebben a szegmensben is komoly akadályozó tényezőt jelent. Éppen ezért a nagyobb, pilóta által vezetett repülő eszközök esetében a belátható jövőben még valószínűleg a gázturbina marad az uralkodó erőforrás (lásd: Dr. Óvári Gyula - Fehér Krisztina: Repülőgépek elektromos meghajtása - szükségszerűség kompromisszumokkal című tanulmányát a Haditechnika 2020/6. és 2021/1. számában - a Szerk.), de kisebb, a szárazföldi alakulatok által is használt eszközöknél összességében egyszerübb megoldás lehet a villamos hajtás alkalmazása.

Szinte minden korszerű hadsereg alkalmaz kis méretű felderítő drónokat olyan esetben, amikor a gázturbina vagy dugattyús motor túl bonyolult megoldást jelent, illetve nagyban rontaná az eszköz felderítő képességeit, de az akkumulátorok által biztosított hatótávolság még megfelelő. A dróntechnika fejlődésével mindeközben felmerült az igény egy nagyobb méretű felderítő-logisztikai, illetve ellátó-sebesültszállító platform létrehozására is. Ebben a méret- és funkciótartományban logisztikai szempontból még mindig nem szívesen alkalmaznak hőerőgépes meghajtást, mivel annak zaj- illetve hőhatása miatt egyébként is nagyon rossz lenne egy ilyen alacsony magasságon működő eszköz túlélőképessége. Ugyanakkor az akkumulátorok tömege már lehetetlenné teszi, hogy elérjék a minimum megkívánt 2-300 km-es operatív hatótávolságot. Ezen a fejlesztési területen komoly előnyt biztosíthat a hidrogén és a PEM-cella együttese, amely ötvözhetné a hőerőgépes meghajtás hatótávolságát a villamos hajtás alacsony karbantartási igényével és korlátozott észlelhetőségével.

\section{E-MOBILTÁS - ÜZEMANYAG-ELLÁTÁS}

Mint minden hadsereg, a Magyar Honvédség is rendelkezik saját üzemanyag-tároló és -elosztó kapacitással. Ennek oka, hogy a „békétől eltérő” időszakban a Magyar Honvédséggel szemben alapvető elvárás, hogy a saját működését meghatározott ideig, a civil infrastruktúrától függetlenül legyen képes biztosítani. Ehhez pedig nyilvánvalóan rendelkeznie kell a megfelelő mennyiségü üzemanyag-tartalékkal, illetve az elosztáshoz szükséges eszközökkel (tartályautók, mobil üzemanyag-átfejtő eszközök, labor stb.).

Amennyiben a hadseregek, köztük a Magyar Honvédség járműflottájában megjelennek az elektromos meghajtású járművek, ezen logika alapján biztosítani kell azok saját tartalékból, saját eszközökkel történő tölthetőségét is. Mivel egy önálló katonai villamos távvezeték-hálózat kiépítése nem tűnik életszerűnek, a szükséges villamos energiát 


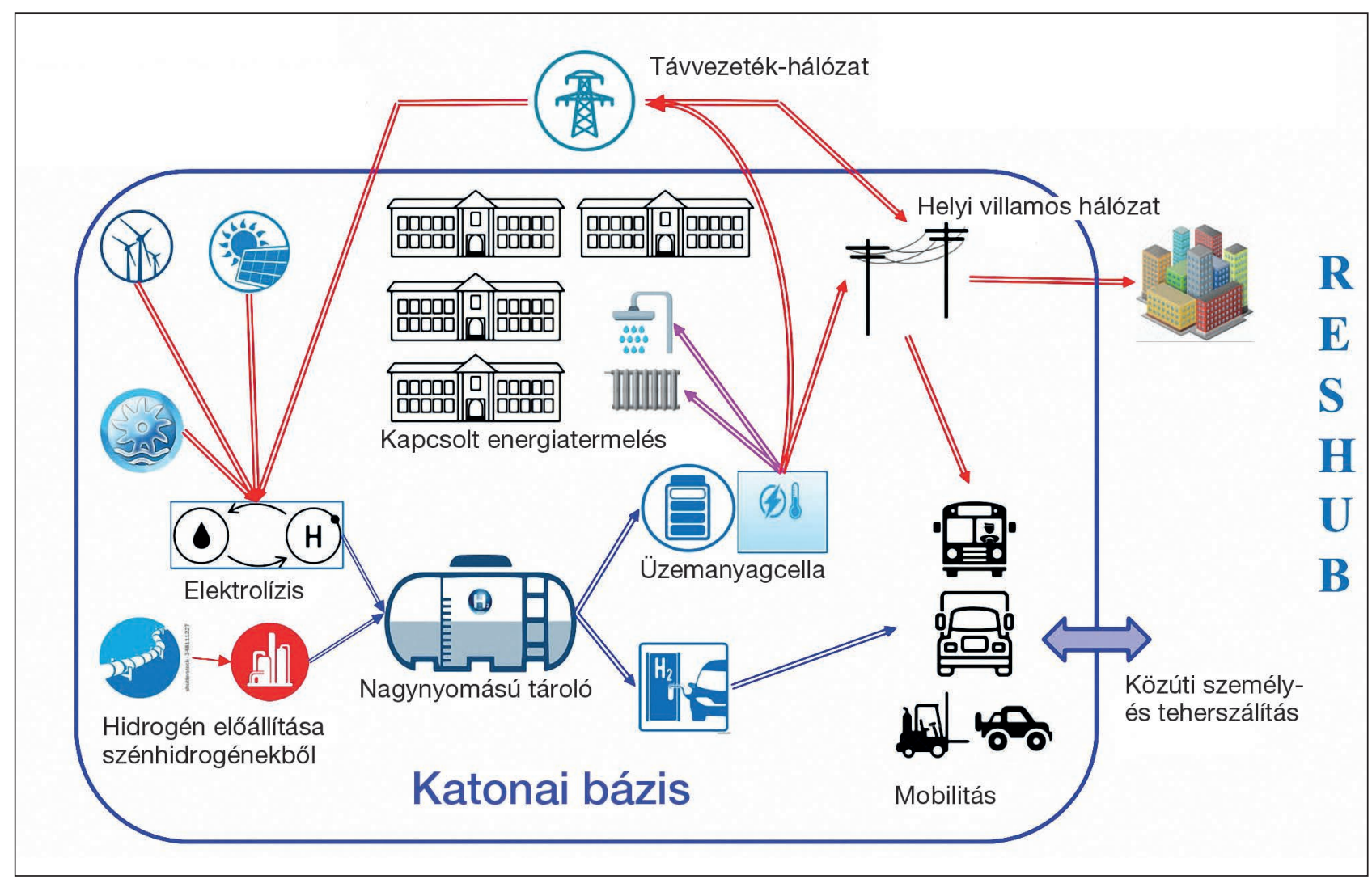

3. ábra. A RESHUB projekt egy objektumának felépítése (Forrás: Szlovén Védelmi Minisztérium)

valamilyen lokális módon kell tárolni. Ha eltekintünk a teoretikusan lehetséges szivattyús-tárolós, lendkerekes vagy még szokatlanabb szupravezetős tekercses technológiáktól, belátható, hogy jelenleg csak az akkumulátoros és a hidrogénalapú tárolási eljárások képesek azt a mobilitást, rugalmasságot és megbízhatóságot biztosítani, amelyek a katonai alkalmazás alapfeltételei. Az akkumulátorok mellett szól az a tény, hogy általánosan használt, és elérhető technikáról van szó, amelynek szinte minden paraméterét tekintve (energia- és teljesítménysűrűség, élettartam) továbbfejleszthető. Ugyanakkor a technológiának van számos olyan hátrányos tulajdonsága is, amely a belátható jövőben továbbra is problémát jelent majd. Ilyenek egyebek között az erős hőmérséklet-függőség (amely katonai alkalmazás esetén fokozottan jelentkezik), és az előállításhoz szükséges ritkaföldfémek elérhetősége, illetve a kitermeléssel járó környezetpusztítás. További kedvezőtlen sajátossága az akkumulátoros technológiának, hogy a tároló és a tárolt energia kinyeréséhez szükséges, vagyis a kémiai energiát villamossággá alakító rész egyetlen fizikai egységet alkot. Ez a gyakorlatban azt jelenti, hogy növekvő tárolt energiaigény esetén a jövőben azzal egyenes arányban nő a tároló tömege, a térfogata, és nem utolsósorban az ára is.

A hidrogén esetében - függetlenül attól, hogy nagynyomású palackban fémabszorbensként, vagy kriogén folyadék formájában tároljuk azt -, a tárolástól elkülönült egységet képez a kémiai energiából villamos energiát előállító eszköz, vagyis a PEM-cella. Növekvő tárolt energiaigény esetén csak a tárolóból (pl. palackból) kell több, a PEMcella kapacitását (és ennek megfelelően a méretét és árát is) csak az adott pillanatban kinyerni kívánt energia menynyisége határozza meg. Természetesen a hidrogénre alapuló tárolásnak is vannak olyan kedvezőtlen tulajdonságai, amelyek a közeli jövőben még korlátot jelenthetnek. Ilyen pl. a determinált maximális hatásfok és a PEM-cellában alkalmazott platina kérdése. Ugyanakkor, ha az energiaigény túlnő a néhány 10 vagy 100 kWh-s tárolási kapacitáson, egyértelműnek tűnik, hogy már jelenleg is a hidrogénes technológia a költséghatékonyabb. Márpedig egy komolyabb méretű gépjármúflotta többnapos energiaigénye minimum 100 MWh-s nagyságrendet jelent.

Ezen a területen már egy részben hazai programról is beszámolhatunk. Az elektromos katonai járművek polgári célú rendszerektől független töltésének kérdésével a nemzetközi szakmai szervezetek is foglalkoznak. Az Európai Védelmi Ügynökség (EDA) 8 támogatásával öt ország fogott össze egy európai védelmi célú villamos töltőhálózat kialakításának érdekében, amely napelemekkel előállított hidrogén tárolásán, és igény szerint, PEM-cellák segítségével előállított elektromosságon alapszik. A 2019-ben elindult RESHUB ${ }^{9}$ projektvezető nemzete Szlovénia. A programban Ausztria, Belgium, Németország és - a Magyar Honvédség Modernizációs Intézete révén - Magyarország vesz részt. Az öt ország sikeresen pályázott az uniós strukturális alapoknál ${ }^{10}$ (első lépésként a megvalósíthatósági tervek elkészítésére), de a COVID-19 vírus okozta helyzetben ennek tényleges végrehajtása csúszik. Magyarországon öt katonai objektum területén alakítanának ki hidrogénalapú töltőpontot. A tervek szerint a hazai katonai töltőállomások úgy helyezkednek majd el, hogy biztosítsák egy, az országon áthaladó szövetséges katonai konvoj ellátását.

A megvalósíthatósági tanulmányok figyelembe veszik a helyi gazdasági és jogi környezetet, megvizsgálják az esetleges túltermelés esetén a befogadó katonai objektum villamos hálózatába történő visszatáplálás lehetőségét, illetve a polgári célú hidrogén és/vagy villamos energia értékesítést is. Ez a kialakítás a Magyar Honvédség szempontjá- 


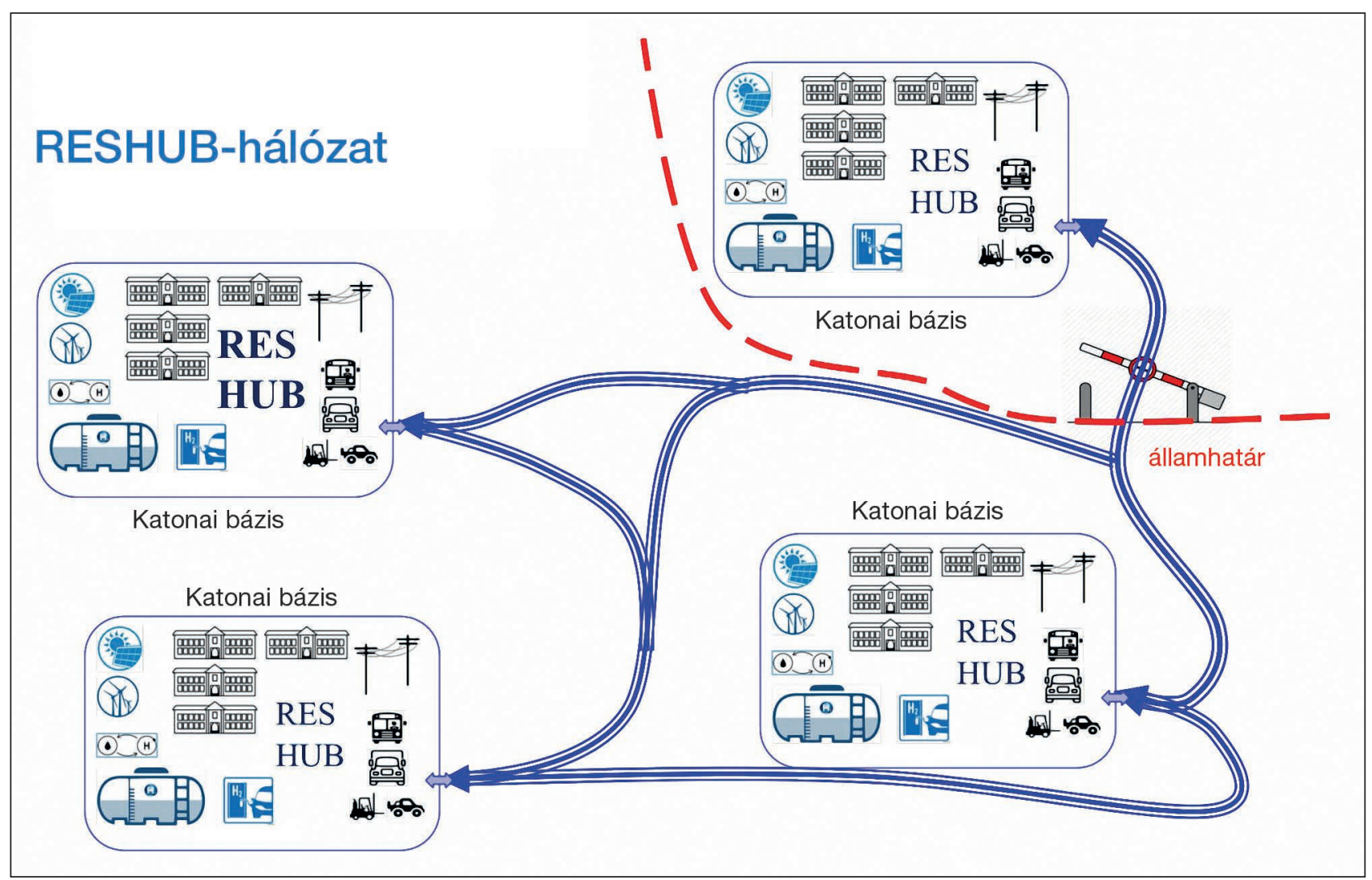

4. ábra. A RESHUB-projekt felépítése (Forrás: Szlovén Védelmi Minisztérium)

ból határozottan előnyös, ugyanis a Magyar Honvédség európai viszonylatban is elismerésre méltó, több mint $500 \mathrm{~kW}$ névleges teljesítményű saját tulajdonú napelemes termelőkapacitással rendelkezik, ami egy éven belül megduplázódik (a tanulmány írásának idején több helyszínen már csak a hivatalos átadás van hátra). $\mathrm{A}$ kiserőművek egy része a termelt áramot képes visszatáplálni a hálózatba, de néhány helyszínen - jogi vagy műszaki gondok miatt - ez nem valósulhatott meg, így jelenleg az aktuálisan a nem felhasznált villamos energia elvész, amit egy elektrolizátor berendezéssel és hidrogénszivattyúval orvosolni lehet.

Amennyiben a RESHUB-projekt megvalósul, azzal a Magyar Honvédség egycsapásra az egyik legjelentősebb magyarországi hidrogénfelhasználóvá lépne elő, de ennél sokkal fontosabb, hogy a hidrogén formájában letárolt energia akkor is rendelkezésre áll, ha éppen nem halad keresztül az országon szövetséges konvoj, amelyet fel kellene tölteni. Ennek segítségével a Magyar Honvédség saját elektromos és/vagy hidrogénüzemü gépjárműflottát is üzemeltethet, vagy visszatáplálhatja az energiát a saját hálózatába, csökkentve az objektum fenntartási költségeit, illetve a többlet villamos energiát akár értékesítheti is.

\section{TÁBORI VILLAMOSENERGIA-ELLÁTÁS}

A modern hadseregek a laktanyákon kívül sem nélkülözhetik a villamos energiát. A konzervatív ellátási rendszer nyomán, a II. világháború idején tábori körülmények között még többnyire petróleummal világítottak és fával fütöttek, az elektromosságot jobbára csak a kommunikációs eszközök üzemeltetésére használták, addig ez mára alaposan megváltozott. A már korábban említett információs fölény érdekében a katonai vezetés soha nem látott mennyiségű infokommunikációs eszközt használ, a csapatok vezetése és irányítása lényegében csaknem kizárólag elektronikus eszközökre épül, ezeket napjainkban csak C4 $4^{11}$ összefoglaló néven említik. Mindezeken túl manapság a világítás, a sátrak és konténerek klimatizálása illetve, az egyéb kiszolgáló létesítmények üzemeltetése is villamos árammal történik.

Ez a tábori körülmények között egyre inkább növekvő villamosság iránti igény napjainkra komoly logisztikai problémát jelent, ugyanis az energiatermelés technológiája lényegében 50 éve változatlan, még mindig hőerőgéppel meghajtott generátorokat, azaz aggregátorokat használ minden haderő. Egy műveleti területen települt katonai alakulat csak addig képes a pozícióját tartani, amíg élnek az utánpótlási vonalai. Márpedig az utánpótlás túlnyomó tartalmi része napjainkban az üzemanyag, aminek egyre jelentősebb arányát nem a harcjárművek, hanem az aggregátorok meghajtására égetik el. Ez egyben azt is jelenti, hogy múveleti területen a fosszilis energiahordozók használatának mérséklése elsősorban nem környezetvédelmi vagy gazdasági kérdés, hanem műveleti előny, ami növeli a települt katonai erő túlélőképességét, autonómiáját. A közelmúlt konfliktusai is rávilágítottak arra a tényre, hogy az ellátó konvojok kedvelt célpontjai az ellenségnek, így a fosszilis üzemanyagok használatának mérséklése emberéletekben is mérhető előnyt jelenthet [5].

Műveleti területen a köznapi értelemben vett üzemanyag-takarékosság nehezen értelmezhető, mivel a katonai célok elérése mindig elsődleges. Tehát a szükséges haditechnikai eszközök működésének korlátozása nem elfogadható, a korszerübb, és így takarékosabb eszközök rendszeresítése (pl. hagyományos izzó helyett LED-es világítás alkalmazása) pedig önmagában nem képes ellensúlyozni a növekvő igényeket. Szintén megoldhatatlan, hogy 


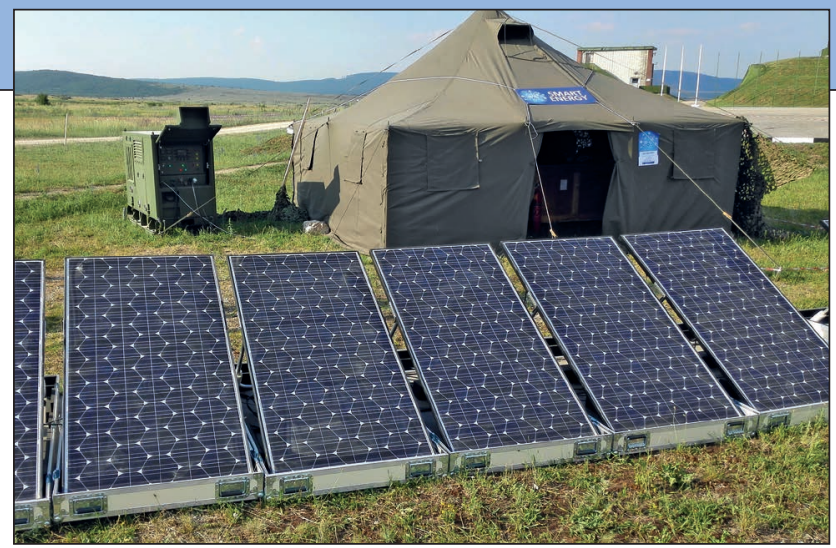

5. ábra. Napelemek és dízelaggregátor egy logisztikai gyakorlaton (Fotó: a szerző saját felvétele)

a katonai egységek az aggregátorok üzemeltetésére a harc- és gépjárművekétől eltérő üzemanyagot használjanak, hiszen ez ugyanúgy utánpótlást igényelne, ráadásul a NATO-ban él az ún. „Egyetlen üzemanyag elve” (SFC) [6] ${ }^{12}$, vagyis a logisztikai ellátás egyszerüsítése érdekében a harctérre kizárólag szabványos összetételű kerozint ${ }^{13}$ szállítanak, és minden hőerőgépet azzal kell üzemeltetni.

llyen körülmények között az egyetlen megoldást a helyben is fellelhető elsődleges energiaforrások, elsősorban a megújuló források felhasználása jelentheti. A biomassza felhasználása külön infrastruktúrát igényelne, a vízenergia és a geotermikus energia felhasználhatóságát pedig a geológiai adottságok és a szükséges infrastruktúra mérete zárja ki. A fennmaradó szél-, és mindenekelőtt a napenergia az a forrás, aminek felhasználásához a szükséges eszközök olyan jól mobilizálhatók és skálázhatók, hogy katonai alkalmazásuk lehetséges. Ezek az elsődleges energiaforrások tehát tábori körülmények között is kiaknázhatók, de nem megbízhatóak, nem mindig állnak rendelkezésre, amikor szükséges, ezért önmagukban alkalmazva nem csökkentik jelentős mértékben az aggregátorok működési idejét. A megoldás itt is a korábban már említett akkumulátoros vagy hidrogénelvű energiatárolás lehet, amellyel már valóban radikális mértékben, akár 60-80\%-kal is csökkenthető az aggregátorok üzemideje. Egy bizonyos kapacitás felett itt is egyre inkább a hidrogén felhasználása tűnik előnyösebbnek, nemcsak a költségek, hanem a szállíthatóságot korlátozó tömeg miatt is. A hidrogén műveleti területen történő alkalmazása nem üközik az egyetlen üzemanyag alkalmazásának elvébe (Single Fuel Concept), mivel azt jellemzően nem odaszállítani, hanem megújuló forrásokból helyben előállítani tervezik.

Természetesen nemzetközi kitekintésben ez a megoldás sem ismeretlen. A már korábban említett EDA, 2014-től önálló munkacsoportot működtet az energetikai és környezeti kérdések ${ }^{14}$ kezelésére, továbbá a NATO tudományos és technológiai szervezete (STO) ${ }^{15}$ is élénken kutatja a területet. Mindkét szervezet munkájának egyik fókuszterülete a hidrogén katonai célú alkalmazása. Magyarországon a Magyar Honvédség Modernizációs Intézete a Zrínyi 2026 Honvédelmi és Haderőfejlesztési Program részeként az elavult aggregátoros berendezések kiváltására egy többéves projektet indított egy olyan hibrid terepi áramellátó komplexum kifejlesztése érdekében, amely megalapozza a hidrogénalapú energiatárolásban rejlő lehetőségek kiaknázását is.

\section{SZEMÉLYI ÉS KISALEGYSÉG SZINTŰ ENERGIAELLÁTÁS}

Napjainkban a haditechnikai fejlesztések terén általános probléma, hogy a konvencionális fejlesztési irányok, mint pl. a páncélvédettség növelése vagy a tűzfegyverek ballisztikai tulajdonságainak javítása, egyre inkább anyagtechnológiai korlátokba ütköznek. Amíg egy új technológia (pl. az energiafegyverek) nem érik el a szükséges technikai színvonalat, addig jellemzően az információs fölény egyfajta lokális megteremtésével igyekeznek a csapatok harcértékét növelni. Ezt a célt szolgálja a GPS, a különféle elektrooptikai irányzékok, éjjellátó berendezések, a műholdas kommunikációs eszközök és zavaróberendezések, illetve akár a drónok alkalmazása is. A gyakorlatban ez azt jelenti, hogy tömegesen jelennek meg új elektronikus eszközök a katonai járművek fedélzetén, és a katonák egyéni felszerelésében is.

A katonai járműfedélzeti eszközök olyan jelentős terhelést jelentenek a jármúvek villamos rendszerére, hogy a tervezők egyre gyakrabban alkalmaznak kiegészítő hajtóműveket annak érdekében, hogy a gépkocsikat álló helyzetben is táplálni tudják. Korábban a fedélzeti akkumulátorok folyamatos működése érdekében járatni kellett a motort. Ami a személyi felszerelést illeti, a NATO-ban általános elvárás, hogy egy katona utánpótlás nélkül három napig önállóan tudjon ténykedni, vagyis az ehhez szükséges valamennyi felszerelést magával kell vinnie. Ez a tömeg - alakulattól és missziótól függően -, akár 30-50 kg is lehet, és ebből jellemzően 5-8 kg a málházott akkumulátorok tömege [7].

A harcjárművek esetében megoldás lehetne egy kis méretű PEM-cellás kiegészítő hajtómű felszerelése, amely álló helyzetben is zajtalanul múködtethetné a fedélzeti elektronikus eszközöket. De minimális tömege, és a már sokszor dicsért zajtalan müködés okán akár a gyalogos katonáknál lévő akkumulátorok feltöltésére is használható lenne. A kérdés rendkívül időszerű, ugyanis a már említett anyagtechnikai korlátok és az információs fölény miatt minden fejlett haderő napirenden tartja a „harctér digitalizálását”, ami azt jelenti, hogy a még a jelenleg alkalmazott infokommuniációs eszközöknél is több infokommunikációs eszköz jelenik meg az első vonalakban. Valójában minden harcjármű és minden katona az alapfunkciójától függetlenül egyben egy szenzorszigetté is válna, így a vezetés minden korábbinál több információhoz juthatna a harctéri helyzetről, a környezeti viszonyokról, a katonák élettani paramétereiről, valamint a harcjárművek állapotáról. A Zrínyi 2026 Honvédelmi és Haderőfejlesztési Program kiemelt célja az ún. „digitális katona architektúra” kialakítása, ahol vizsgáljuk a hidrogénalapú eszközök rendszeresítésének lehetőségét a személyi felszerelések között. Csupán érdekesség, hogy ebben a kontextusban a hidrogén alkalmazása már ellentmond a Single Fuel Concept elvének, ennek ellenére, mind az EDA, mind a NATO STO is folytat hasonló jellegü kísérleteket.

Büszkén jelenthetjük, hogy e területen is létezik magyar kutatás. A Magyar Honvédség Modernizációs Intézete a svájci Szövetségi Védelmi Beruházási Irodával együttmúködve - a magyar Természettudományi Kutatóközpont Anyag- és Környezetkémiai Intézete és a svájci Szövetségi Technológiai Intézet munkatársainak bevonásával - egy komoly vizsgálat lefolytatására készül. A kutatás tárgya az akkumulátoros és a hidrogénes energiatárolási technika harctéri alkalmazhatóságának összehasonlítása. A vizsgálat során nemcsak a villamos paraméterek összehasonlítására kerül sor, hanem kísérleti úton tanulmányozzuk, hogyan reagálnak a különféle energiatárolók, ha lövés vagy repesz okozta találat éri azokat.

\section{ÖsszeGzés}

Egyre több jel utal arra, hogy a hidrogénre alapuló energetikai megoldások elérték azt a technológiai szintet, amikor széles körben és gazdaságosan alkalmazhatóvá válnak. 
Napjaink környezetvédelmi, biztonságpolitikai és gazdasági kihívásai is indokolttá teszik, hogy a jövőben számoljunk ezzel a lehetőséggel. A Zrínyi 2026 Honvédelmi és Haderőfejlesztési Programnak köszönhetően a Magyar Honvédség számos területen megújul. Remek lehetőség nyílik arra, hogyhogy ne csak kövesse az aktuális technikai fejlesztési irányokat, hanem részesévé, vagy akár egyik vezető erejévé is váljon azoknak. A hidrogén az egyik olyan terület, ahol számos katonai alkalmazás elképzelhető, így kiváló lehetőség nyílik a hazai ipari és akadémiai szektorral történő együttmüködésre.

\section{FELHASZNÁLT IRODALOM}

[1] R. Bryce. „Gas Pains”, The Atlantic, máj. 2005. Elérés: 2020. 11. 13. https://www.theatlantic.com/magazine/ archive/2005/05/gas-pains/303897;

[2] Király László és Végvári Zsolt, „Energiahatékonyság a Magyar Honvédség béke időszaki működésében”, Hadtudomány 27, sz. 3-4 (2017. nov): 54-73. https://doi.org/10.17047/HADTUD.2017.27.3-4.54;

[3] Ocskay István és Végvári Zsolt. „A hidrogén üzemanyagcellák katonai célú felhasználásának lehetőségei”, Haditechnika, 53, 2. sz. (2019): 14-19. o. https://doi.org/10.23713/HT.53.2.03;

[4] „GM's view of hydrogen fuel cells: great for military use". Elérés: 2020. 11. 13.

https://www.greencarreports.com/news/1113209 gms-view-of-hydrogen-fuel-cells-great-for-military-use;

[5] C. Helman. „More Oil Means More Death”, Forbes, nov. 12, 2009. Elérés: 2020. 11. 13. https://www.forbes.com/2009/11/12/fuel-militaryafghanistan-iraq-business-energy-military.html;

[6] "Chapter 8: Petroleum Support”, in NATO Logistics Handbook, Brussels: NATO HQ, 2012, o. 95-104.;
[7] Márkus Ferenc. „A gyalogos lövészkatona egyéni harcászati felszerelésének modernizálási lehetőségei a Magyar Honvédségben", Seregszemle, köt. 11, sz. 2-3, o. 7-21., máj. 2013.

\section{JegYZetEK}

1 További információk: https://www.hfc-hungary.org/platform/.

$2 \mathrm{Az}$ angolszász irodalomban a nagyobb energiamennyiségeket gyakorta nyersolaj ekvivalens mértékben adják meg. 1 liter nyersolaj energiatartalma kb. $41 \mathrm{MJ}$.

$3 \mathrm{Az}$ információs fölény azt jelenti, hogy több és pontosabb információval rendelkezünk a saját és az ellenséges csapatokról és környezetről, mint az ellenség. Ennek birtokában hozhatók meg azok a helyes döntések, amelyek biztosítják a műveleti fölényt, ez által a győzelmet.

4 PEM: Proton Exchange Membrane - protonáteresztő membrános tüzelőanyag-cella.

5 Marcus Porcius Cato Maior ókori római író, történetíró, államférfi (i.e. 234-149) Origines (Eredetek) című munkája nyomán Plinius jegyezte fel Hannibál kedvenc elefántjának, SURUS-nak a nevét. A SURUS szó felhasználásával Tom Clancy kreálta a Silent Utility Rover Universal Superstructure (kb. csendes hasznos vándorló univerzális szuperszerkezet) kifejezést. Ezt a nevet kapta a GM fejlesztése. (- Szerk.)

6400 mérföld: mintegy $644 \mathrm{~km}$

7 A Magyar Honvédség szempontjából jelen tanulmány szerzője „béke időszak"-nak tekint minden olyan időszakot, amelyre nem vonatkozik a Magyarország alaptörvényének 48-54. cikke szerinti különleges jogrend.

8 European Defence Agency - EDA

9 Defence RESilience HUB Network in Europe.

10 SRSP - Structural Reform Support Programme.

11 Command, Control, Communication and Computers.

12 Single Fuel Concept.

13 NATO-kód: F-34.

14 Energy \& Environment Working Group.

15 NATO Science and Technology Organization (STO).

\section{HM ZRÍNYI TÉRKÉPÉSZETI ÉS KOMMUNIKÁCIÓS SZOLGÁLTATÓ KÖZHASZNÚ NKFT.}

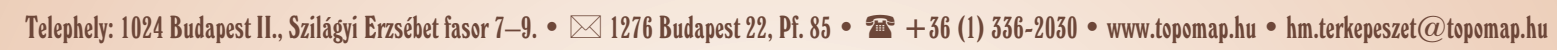

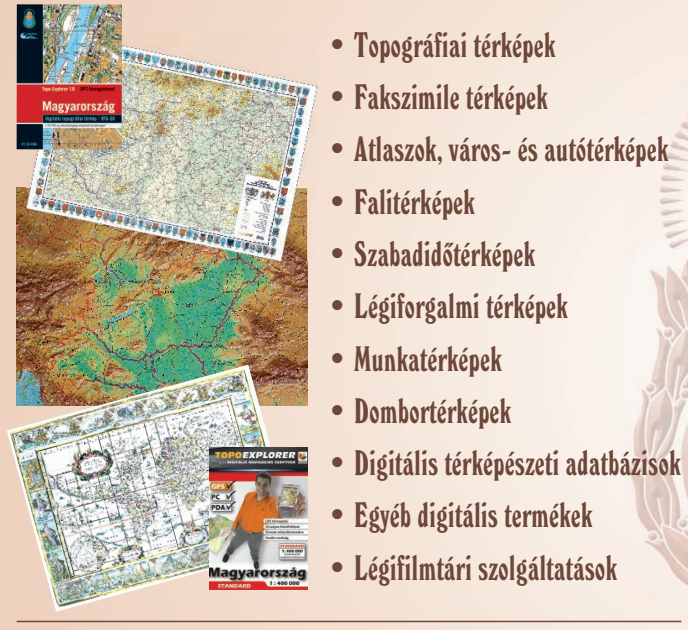

ÜGYFÉLSZOLGÁLAT ÉS TÉRKÉPBOLT:

1024 Budapest II., Fillér u. 14.

寓 +36 (1) 212-4540・uǵffelszolgalat@topomap.hu Nyitva tartás: hétfö-péntek 9.00-16.30
- PrePress - Nyomdai elökészítés

- szöveg-grafika- és képfeldolgozás, kiadványszerkesztés

- ellenőrzó nyomatok, digitális proofok előállítása

- bel-és kültéri tablók, bannerek nyomtatása

- hagyományos és elektronikus montírozás, színrebontás

- nyomóformák elóállítása nyomdai filmról, illetve CTP-technológiával

- Gyorssokszorositás

- színes és fekete-fehér másolás/nyomtatás 330 x 487 mm méretig

- Press - Nyomtatás

- ofszetnyomtatás négy-, illetve hatszínnyomó gépeken, 89 x $126 \mathrm{~cm}$ méretig

- PostPress - Kötészeti feldolgozás

- felïletnemesítés fóliázással, laminálással 167 cm szélességig

- hajtogatás, spirálozás, sorszámozás

- összehordás, irkakészítés, ragasztókötés

- kasírozás, táblakészítés, aranyozás

- szortiment könyvkötészet

- Vákuumformázás

- vákuumformázó szerszámok, terepasztalok előállítása CNC-technológiával - vákuumformázás

NYOMDAI GYÁRTÁSELŐKÉSZÍTÉS: 雨 + 36 (1) 336-2035 